\title{
On the Road to Ariel:
}

\section{The "Transitional" Poetry of Sylvia Plath}

\section{Marjorie G. Perloff}

During the past year or so, Sylvia Plath has become a true cult figure. At this writing, the Savile Book Shop in Georgetown, D.C. has a huge window display in which copies of The Colossus, The Bell Jar, Ariel, and Crossing the Water encircle a large photograph of Sylvia Plath, which rests against a copy of A. Alvarez's The Savage God: A Study of Suicide, that ultimate tribute to Sylvia Plath as our Extremist Poet par excellence.

In the face of such publicity, the poems themselves become almost an irrelevancy in the search for the real Sylvia Plath, the Laingian heroine behind the mask of beautiful, brilliant, super-efficient Smith girl, who married the most admired British poet of our time. Yet in the long run it is, of course, the poetry and not the life of the suicidal poet that matters, and I do not think that the cause of Sylvia Plath's poetry is particularly well served by the recent publication of two volumes of previously uncollected poems: Crossing the Water and Winter Trees. ${ }^{1}$ To read the Ariel poems in the context of these "new" volumes, is somewhat like trying to concentrate on Renoir's great "La Source" of 1875 in the Barnes Foundation, where it hangs on a large wall full of third-rate Renoirs. In such a setting, the power of the major work of art may well be dissipated rather than enhanced.

To begin with, both of these volumes show signs of very careless editing on the part of Ted Hughes. Crossing the Water is subtitled Transitional Poems, and according to the dust jacket, "The poems in this collection were written in the period between the publication of The Colossus (1960) and the posthumous book Ariel (published in England in 1965). As a group, they illuminate an extremely important period in Sylvia Plath's life; they also mark the point at which her work moved beyond great promise and competence and began to burn with genius." Reviewers, following this lead, began to speak of Sylvia Plath's transitional style. Thus Douglas Dunn wrote in Encounter: "Sustained poems of great quality are gathered in this . . . indispensable book" which is "much freer in style" than Plath's early work, and Lyman Andrews said in the London Sunday Times: "Assurance was sometimes lacking in her earlier poems, and in the last poems at times there was a loss of control, while these poems are an almost perfect marriage of strength and elegance." Ted Hughes himself, discussing the volume in a BBC broadcast, said: "This work from the interim is fascinating and

\footnotetext{
1 Crossing the Water (New York: Harper \& Row, 1971); Winter Trees (London: Faber and Faber, 1971).
} 
much of it beautiful in a rich and easy way that we find neither in The Colossus nor Ariel."2

These are rather extravagant claims for, in fact, almost half the poems in Crossing the Water belong to the period of The Colossus! Of the thirty-eight poems in the volume, eleven were published before the end of 1960, and internal evidence suggests that an additional six were written in late 1959 or early $1960 . .^{3}$ On the other hand, certain poems in Crossing are contemporaneous with certain Ariel poems. "In Plaster," for example, is the companion poem to "Tulips" (Ariel, p. 10); both were written in March 1961 when Sylvia Plath was recovering from an appendectomy. 4 The confusion is further compounded by Hughes' prefatory note to Winter Trees: "The poems in this volume are all out of the batch from which the Ariel poems were more or less arbitrarily chosen and they were all composed in the last nine months of Sylvia Plath's life." But three of these eighteen "new" poems-"Lesbos," "The Swarm," and "Mary's Song"-are, it turns out, Ariel poems, for although they had not been included in the British edition of 1965, they did appear in the U.S. edition of 1966, which is the text of the current Harper paperback.

If a poem as well known as "Lesbos" is reprinted in Winter Trees, why are so

2 Douglas Dunn, Encounter, 37 (August 1971), 68; Ted Hughes, "Sylvia Plath's Crossing the Water: Some Reflections," Critical Quarterly, 13 (Summer 1971), 165. Lyman Andrews' comment is reprinted on the dust jacket of Crossing the Water.

3 One can easily check the dates of magazine publication of Plath's poems by consulting the Plath Bibliography by Mary Kinzie, Daniel Lynn Conrad, and Suzanne D. Kurman in The Art of Sylvia Plath, ed. Charles Newman (London: Faber and Faber, 1970), 305-19. The bibliography makes clear that the following poems were published before the end of 1960: "Candles," "Black Rook in Rainy Weather," "Metaphors," "Maudlin," "Ouija," "Two Sisters of Persephone," "Who," "Dark House," "Maenad," "The Beast," "Witch Burning." Of these, the two earliest are "Two Sisters of Persephone," first published in the January 1957 issue of Poetry, and "Black Rook in Rainy Weather," originally published in Granta in May 1957. All the rest, except for "Candles," which appeared in The Listener on November 17, 1960, were first published in the British edition of The Colossus in the late fall of 1960. Five of these poems-"Who," "Dark House," "Maenad," "The Beast," and "Witch Burning"-were originally part of the sevenpoem sequence, Poem for a Birthday, written at Yadoo in late 1959. The remaining two poems in this sequence-"Flute Notes from a Reedy Point" and "The Stones"-were published as separate poems in the U.S. edition of The Colossus (1962).

I believe that the following poems were written before 1960: "Private Ground," "Sleep in the Mojave Desert," "Two Campers in Cloud Country," "On Deck," "Crossing the Water," and "Finisterre." Most of these poems refer specifically to the camping trip across the United States and Canada which Sylvia Plath and Ted Hughes took in the summer of 1959. Since Plath's poems always stem from her immediate experience, it is highly unlikely that she would have used settings such as Rock Lake, Canada or the Mojave Desert a year or two after the trip at a time when she was living in England.

4 Ted Hughes calls "In Plaster" the "weaker twin" of "Tulips" and says that it was written "at the same time and in almost identical form," "The Chronological Order of Sylvia Plath's Poems," The Art of Sylvia Plath, p. 193. 
many other poems, which appeared in leading periodicals both before and after Sylvia Plath's death, omitted from both new volumes? "Ouija," for example, originally appeared in the Hudson Review (Fall 1960) together with "Electra on Azalea Path"; the first is included in Crossing (p. 44), the second omitted. No explanations are given. Yet "Electra," an earlier variant of the famous "Daddy," seems at least as relevant to a study of Plath's interim work as does "Ouija." Again, all the poems published in the March 1962 issue of Poetry-"Widow," "Face Lift," "Heavy Women," and "Love Letter"-find their way into Crossing, with the exception of "Stars Over Dordogne." "Purdah," published posthumously in Poetry in August 1963 appears in Winter Trees, but its companion poem, "Eavesdropper," an interesting analogue to "Lesbos," does not. And "The Jailor," published in Encounter in October 1963 is not reprinted in Winter Trees, although "Thalidomide" and "Childless Woman," printed in the same issue, are.

In view of these discrepancies and errors, we will have to wait for a Collected Poems, tentatively scheduled for publication by Faber and Faber in 1973 (and hopefully more carefully edited!), before we can venture to assess Sylvia Plath's place in the history of modern poetry. What follows is, accordingly, in the nature of an interim report.

We may profitably begin our consideration of Crossing the Water by looking at a representative poem that really is "transitional": "Parliament Hill Fields" (p. 7), which first appeared in the London Magazine in August 1961 and has as its subject the miscarriage Sylvia Plath suffered less than a year after her first child Frieda was born. 5

In Plath's poetry, pregnancy is usually regarded as a temporary suspension of anxiety, for carrying a child gives the poet a sense of being, of having weight, of inhabiting her own body. In "Letter in November," for example, the speaker says:

I am flushed and warm.

I think I may be enormous,

I am so stupidly happy,

My Wellingtons

Squelching and squelching through the beautiful red. (Ariel, p. 46)

Conversely, the termination of pregnancy is seen as a frightening state in which one feels weightless, empty, disembodied. So, in "Parliament Hill Fields," the poet mourns, not for the loss of her baby as a new human being whom she might have loved and cared for, but rather for the loss of a vital part of herself, without which she becomes a sheer vacuum, an empty vessel. Plath's use of nature imagery in this poem may be glossed by the following account of the childhood experience of a mental patient, which R. D. Laing cites in The Di-

5 See Lois Ames, "Notes Toward a Biography," The Art of Sylvia Plath, p. 170. 
vided Self as an example of the schizophrenic's typical fear of engulfment, the fear that other selves threaten to absorb one's already fragile identity, and implosion, the terrible impingement of reality upon the empty self:

I was about twelve, and had to walk to my father's shop through a large park, which was a long, dreary walk. I suppose, too, that I was rather scared. I didn't like it, especially when it was getting dark. I started to play a game to help pass the time. . . . It struck me that if I stared long enough at the environment that I would blend with it and disappear just as if the place was empty and I had disappeared. It is as if you get yourself to feel you don't know who you are or where you are. To blend into the scenery so to speak. Then you are scared of it because it begins to come on without encouragement. I would just be walking along and felt that I had blended with the landscape. Then I would get frightened and repeat my name over and over again to bring me back to life, so to speak. 6

The tension described here between the desire to "blend into the scenery," thus becoming invisible and beyond attack, and the opposite urge to maintain one's autonomy as a person, is precisely the theme of "Parliament Hill Fields." Sylvia Plath's poem is above all a poem of absence, absence not only of others but of oneself: witness the opening stanza:

On this bald hill the new year hones its edge.

Faceless and pale as china

The round sky goes on minding its business.

Your absence is inconspicuous;

Nobody can tell what I lack.

As she strolls on Parliament Hill, the highest point of Hampstead Heath, which overlooks the city of London far below, the poet longs to blend with the "bald hill" and "Faceless" sky, for if she can only disappear completely, "Nobody can tell what I lack." Gradually, "the city melts like sugar" and an "ashen smudge" covers Kentish Town, transforming the vista into "a snowfield or a cloudbank." The poet envies the "dark-boughed cypresses" that "Brood, rooted in their heaped losses" and longs to dissolve into the "spindling rivulets" that "Unspool and spend themselves" as "The day empties its images/ Like a cup or a room."

But despite this longing for dissolution, a part of the self still struggles for autonomy. Surrounded by alien selves that seem to assert their own being remorselessly, the poet withdraws further and further into her own isolation. Thus the very gulls frighten her, "stirring like blown paper/ Or the hands of an invalid." Next, "A crocodile of small girls/ Knotting and stopping, ill-assorted, in blue uniforms,/ Opens to swallow me." The poet can respond to this danger only by self-petrifaction: "I'm a stone, a stick." Having turned herself into a

6 The Divided Self (1960; rpt. Pelican Books, 1965), p. 110. 
hard, frozen substance, she need no longer fear the "crocodile" of schoolgirls: "Their shrill, gravelly gossip's funneled off." But one threat gives way to another: the wind tries to stop her breath "like a bandage," and even the new moon seems to cut through her like a knife: "The moon's crook whitens,/ Thin as the skin seaming a scar." As night falls and she remembers that she must return to her other baby, the one that did not die, who is asleep indoors, she suddenly imagines that the trivial little picture on the nursery wall has come ominously alive: "The blue night plants, the little pale blue hill/ In your sister's birthday picture starts to glow" and "Each rabbit-eared/ Blue shrub behind the glass/ Exhales an indigo nimbus,/ A sort of cellophane balloon." Reality thus becomes increasingly oppressive, swallowing her up, depriving her of oxygen. Finally, however, just as Laing's patient repeats her name over and over again so as to bring herself back to life, the speaker of "Parliament Hill Fields" forces herself to remember "The old dregs, the old difficulties" and enters "the lit house."

Thematically, "Parliament Hill Fields" is very much like the Ariel poems. "Little Fugue" (p. 70), for example, similarly explores the precariousness of identity, the fear of being alive, the longing for dissolution, and the imagery of absence so prominent in the earlier poem-"bald hill," "Faceless and pale as china," "wan/ Sun," "ashen smudge," "snowfield," "cloudbank"-reappears in the "featurelessness" of the "cold clouds" which is one of the dominant motifs of "Little Fugue."

But "Parliament Hill Fields" is much more conventional than "Little Fugue" in terms of its tone and structure; it often substitutes contrivance for emotional coherence. Ostensibly, the poem records, in sequential form, the process whereby the self becomes increasingly disembodied until the final effort to "snap out of it," to return to reality is made. But the voice of the middle stanzas is oddly knowing and explicit: it is difficult to believe in disembodiment in the case of an "I" that makes such statements as "You know me less constant,/ Ghost of a leaf, ghost of a bird," or "Your cry fades like the cry of a gnat./ I lose sight of you on your blind journey." What we miss here is a rendition of the poet's mental processes themselves rather than such after-the-fact rationalizations of them.

The sound structure bears this out. Throughout the ten six-line free verse stanzas, with their short choppy phrases, enjambement, and strong caesurae, Sylvia Plath invents elaborate phonetic patterns, as in the penultimate line of the poem:

\section{Gulls stiffen to their chill vigil in the drafty half-light.}

Surely this is a virtuoso line: it contains alliteration of f's, l's, and t's, assonance of short is and a's, two examples of internal rhyme ("chill"/ "-gil" and "draf-"/ "half"), and consonance ("gull"/ "chill"/"-gil"). But no sound device can save this line from being pretentious. The gulls must turn cold and "stiffen" at this point for no better reason than that the poet needs to find an objective correlative for her fear. It is she, of course, who must "stiffen" to her "chill vigil" in 
the "half-light" which is euphoniously but all too conveniently "drafty."

"Little Fugue," I would argue, is a much more satisfying poem. The use of the fugue as structural principle is particularly effective here, for the whole poem is a polyphonic composition based on two basic themes which appear in the first two lines of the poem:

The yew's black fingers wag;

Cold clouds go over.

Both the black yew and the cold cloud symbolize suffering and death, but the former is active, the latter the passive death of annihilation. The poet says, "I like black statements," whereas she is terribly afraid of "The featurelessness of that cloud now!/ White as an eye all over!"

The key words "white," "black," "fingers," "ear," and "eye" are now submitted to elaborate contrapuntal treatment. The black yew, for example, is associated in the poet's mind with great passion-"The yew hedge of the Grosse Fuge" -and thus with the love she felt for her father: "Such a dark funnel, my father!/ I see your voice/ Black and leafy, as in my childhood." But the memory is not happy; the father image is transformed into a "yew hedge of orders,/ Gothic and barbarous, pure German." At this point, the suffering triggered by the memory becomes most intense; the yew is associated with Christ and then turned into a pun: "And you, during the Great War. . . "Finally, the poet makes a specific connection between her father's death and the yew: "Death opened, like a black tree, blackly."

The image of the cold cloud undergoes similar metamorphoses. In rapid transformation, it becomes "the eye of the blind pianist/ At my table on the ship," and in the fourth stanza, "Black yew,/ White cloud" refer to the keys on which the pianist performs the Grosse Fuge. Then, after the sudden intrusion of her dead father's image, the poet returns to the first motif: "Now similar clouds/ Are spreading their vacuous sheets." Finally, she sees them as "a marriage dress, of that pallor," the symbol of her impending marriage with death.

Because "Little Fugue" is primarily a composition in black and white, the introduction of bright color in stanza 9 comes as a shock. It is important to note that the only color images in the poem refer to the dead father:

And you, during the Great War

In the California delicatessen

Lopping the sausages!

They color my sleep,

Red, mottled, like cut necks.

The butcher knife seems to cut right through the poet. She sees her father not as a person but in terms of oddly distinct attributes: "You had one leg, and a Prussian mind. . . . I remember a blue eye,/ A briefcase of tangerines." The 
bright colors-red, blue, tangerine- associated with the father image are more than the speaker can bear. The image is expelled and she is left with the recognition of the black and white of death.

A second set of images developed contrapuntally in "Little Fugue" is that of eyes, ears, and fingers. The poem begins:

The yew's black fingers wag;

Cold clouds go over.

So the deaf and dumb

Signal the blind and are ignored.

The third and fourth lines are ambiguous. In one sense, the poet herself is "deaf and dumb," and it is her signal to the blind pianist that is ignored. But when we read these lines in the context of the whole poem, they have a further irony: the dead father, who is deaf and dumb, signals his daughter, who would like to be blind to his image but cannot ignore it. The daughter's terrible fate is that she can only see, not feel. Thus she envies the blind pianist whose "fingers had the noses of weasels" and who "could hear Beethoven." "I couldn't stop looking," she says. This fear of her own vision culminates in the climactic line, almost midway through the poem, "I see your voice." Note that the father says nothing (1. 43), and indeed his daughter calls herself "lame in memory." Because he is defined only in terms of loud color and distasteful action, never in terms of his words, his presence is all the more elusive and menacing. The last stanza is particularly poignant:

I survive the while,

Arranging my morning.

These are my fingers, this my baby.

The clouds are a marriage dress, of that pallor.

Here, as in "Parliament Hill Fields," the speaker tries to convince herself that despite her suffering she is alive, that she is a survivor. She must work at "Arranging" her morning; she must reassure herself that "These are my fingers, this my baby." But her fingers, unlike those of the pianist, which have "the noses of weasels," or the "black fingers" of the yew tree, are wholly lifeless. She has to remind herself what they are just as she seems to have forgotten that she has a baby.

This odd lapse of memory suggests that the title "Little Fugue" has a second meaning. A fugue, according to the Random House Dictionary, is a psychiatric term for "a period during which a patient suffers from loss of memory, often begins a new life, and upon recovery, remembers nothing of the amnesic period." In Plath's poem this meaning is neatly inverted. The poet cannot remember her real situation because the visual image of her dead father blocks her mind. The only way for her to forget him, to undergo a fugue leading to "recovery" and a "new life," is to die. 
To see how carefully Sylvia Plath organizes her central images in "Little Fugue," a diagram might be helpful.

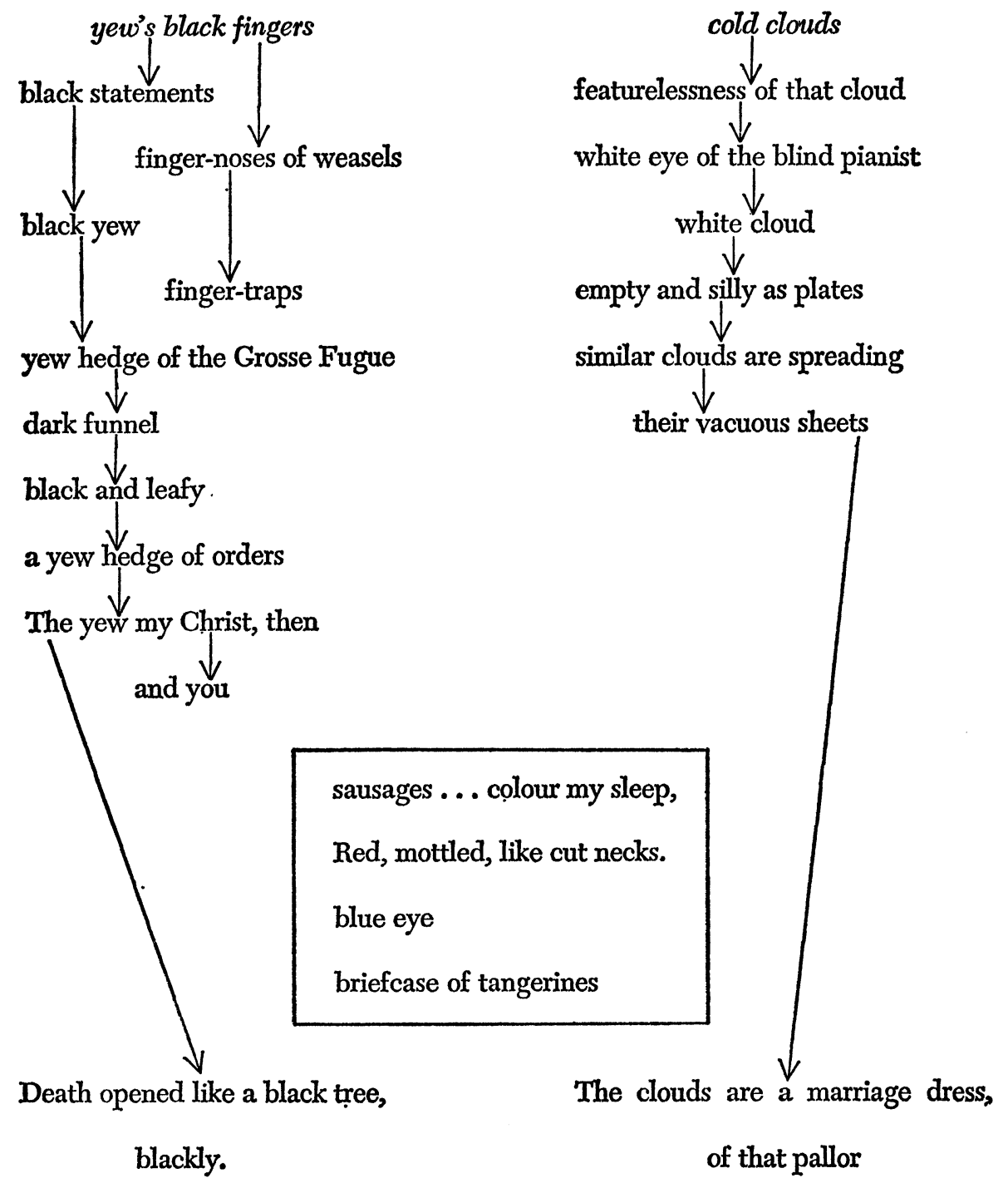


In diagramming "Little Fugue" in this way, I wish to emphasize the poem's economy of statement. In "Parliament Hill Fields," Sylvia Plath introduces a whole string of images, all of which point to the same fear of engulfment: the crocodile of girls, the wind that stops the poet's breath "like a bandage," the "ashen smudge" that "Swaddles roof and tree," and so on. Lines-or, for that matter, whole stanzas-could be reversed without changing the poem appreciably. Occasionally, moreover, the tone of the poem is, as I argued earlier, too self-indulgent: "I suppose it's pointless to think of you at all," "I lose sight of you on your blind journey," and especially the line, "The old dregs, the old difficulties take me to wife."

In "Little Fugue," Sylvia Plath works the other way around. She uses a very limited number of carefully chosen images but gives them every possible sort of variation and resonance. The speaker does not tell us that she suffers; rather, we catch her in the very process of trying to blot out the image of her dead father. We see him through her eyes as a kind of nightmare figure, "Lopping the sausages" in the "California delicatessen." Furthermore, the speaker's intense suffering is objectified and distanced by the poem's syntax and sound. "Little Fugue" is made up of a series of simple declarative sentences, seemingly unrelated to one another: "The yew's black fingers wag," "Cold clouds go over," "I like black statements." It is as if the poet must grope, in fragmentary fashion, for some kind of connection between these disparate items. The short endstopped three and four-stress lines convey the rapid movement whereby images arise in the poet's mind only to be dispelled and transformed. The abrupt movement culminates in what is appropriately the longest line in the poem:

\section{the clóuds/ are a márriage/ dréss/ of thát/ pállor}

with its five heavy stresses, frequent breaks and feminine endings.

If "Parliament Hill Fields" and "Little Fugue" are representative poems, it would seem that the so-called "transitional" mode of Crossing the Water is quite simply the mode of Ariel in its early, tentative, often prolix form. To talk of the "interim work" as if it were really a distinct phase in Plath's poetic development -like, say, Eliot's Sweeney period-is to make unnecessarily large claims for it. Let us see why this is so in the case of the volume as a whole.

\section{II}

The poems in Crossing the Water fall into roughly five thematic groups: (1) moralized landscapes in the vein of "Parliament Hill Fields" and many of the Colossus poems (e.g., "Wuthering Heights," "Finisterre," "Private Ground," "Sleep in the Mojave Desert," "Two Campers in Cloud Country," "Crossing the Water"); (2) hospital poems- that is, poems describing the pain or bizarre incongruities of life on the medical ward or in the mental hospital, usually from the point of view of the speaker as patient ("In Plaster," "Face Lift," "Insomniac," "The Surgeon at 2 A. M."); (3) poems about pregnancy, giving birth, or 
the relationship of mother to infant ("Heavy Women," "Magi," "Love Letter," "Candles," "Small Hours," "Metaphors"); (4) character sketches or surrealistic portrayals of personal relationships, expressing the poet's fear, suspicion, or hatred, especially of other women ("Leaving Early," "Widow," "Two Sisters of Persephone," "The Babysitters"); and (5) poems explicitly about death, the wish to lose consciousness, the longing to transcend the self ("Blackberrying," "I Am Vertical," "Last Words").

This is not, of course, a hard and fast classification. "Blackberrying," for example, could also be placed in the first group, "Parliament Hill Fields" in the third or fifth. The very fact that there is a good deal of overlap shows that Sylvia Plath's thematic range is fairly small. On the other hand, the classification may be helpful in tracing Sylvia Plath's use of a particular genre, her drive to remold it to her own purposes.

Compare, for example, "Leaving Early" in Crossing the Water to "Lesbos" in Ariel. Both poems fall into the fourth category above, having as their subject matter the hostility between the "I" of the poet and another unnamed woman. In both poems, the furnishings of the other woman's house become emblematic of what the speaker senses to be her "friend's" aggressiveness, hypocrisy, and bad taste; in both cases, the reader recognizes that the friend is hated and reviled because the poet really hates herself, because her own sense of identity is so weak that she must fear the other woman's offer of friendship as a threatening intrusion. In "Leaving Early," the decor consists of a strange assortment of dead flowers, rotting in assorted vases, pots, and jugs among the red velvet sofa cushions, magenta sofa, and mirrored walls. In "Lesbos," the emphasis is on the vulgar modernity of a neighbor's "all Hollywood, windowless" kitchen, with its "fluorescent light wincing on and off like a terrible migraine," "Coy paper strips for doors," and the pervasive "stink of fat and baby crap."

But "Leaving Early" lacks the dramatic tension of "Lesbos." Sylvia Plath spins a series of variations on the statement of the opening line: "Lady, your room is lousy with flowers." The red geraniums that "stink of armpits," the dead roses whose "yellow corsets were ready to split," and the crysanthemums "the size/ of Holofernes' head" surrealistically loom larger and larger until the musty odor all but chokes the speaker:

\section{Lady, what am I doing \\ With a lung full of dust and a tongue of wood, Knee-deep in the cold and swamped by flowers?}

A sense of violent unease emanates from these lines, but what is behind the macabre Gothic trappings of "Leaving Early"? The poet succeeds in expressing her personal antipathy for the other woman, but it is difficult to relate her private hostility to a larger human situation. The writing of "Leaving Early" may well have been cathartic for Sylvia Plath, but her irritation, sarcasm, and outrage are not sufficiently objectified.

"Lesbos" is a much more complex poem, contrasting two opposite female 
roles: that of the modern streamlined wife, who has "blown [her] tubes like a bad radio" and seeks ways of dominating others so as to fill the enormous void in her life, and that of the "I," neurotic, "doped and thick from my last sleeping pill," necessarily hypocritical in dealing with her neighbor when it comes to protecting her children, but insisting on her autonomy and freedom: "Even in your Zen heaven we shan't meet." The poet is victim, the other woman victimizer, "kleptomaniac," suburban Gorgon. "Lesbos" is like a miniature novel, a condensed statement about the false relationship between "enlightened" young mothers in the world of the modern apartment complex.

The sound structure of "Lesbos" is also much more effective than the rather flaccid blank verse of "Leaving Early," with its somewhat tiresome alliteration and assonance:

Musky as a lovebed the morning after.

My nostrils prickle with nostalgia.

Compare the following passage from "Lesbos," with its jagged line lengths and subtle rhyme:

Your voice my ear-ring,

Flapping and sucking, blood-loving bat.

That is that. That is that.

You peer from the door,

Sad hag. "Every woman's a whore.

I can't communicate."

I see your cute decor

Close on you like the fist of a baby....

Here the ironic repetion of "That is that," rhyming with "bat," reminds one of the Michelangelo refrain of "Prufrock," as does the rhyme of "whore"/ "decor," whose implication is that the latter is a reflection of the former. The language is wholly colloquial and yet the sound pattern is highly wrought, for example the repetition of the suffix "-ing," rhyming with "ring" or the consonance of "-cate"/ "cute."

Just as "Leaving Early" is an earlier, slighter version of "Lesbos," so poems like "Face Lift" and "Insomniac" seem like early sketches for "Tulips" or "Fever $103^{\circ}$." "Face Lift" (p. 5) is a dramatic monologue, a genre that Sylvia Plath, with her intensely personal, oracular vision, 7 never really mastered. The poem splits into two parts: the voice of an " $\mathrm{I}$ " who reacts intensely to the world of operating rooms, and sounds precisely like Sylvia Plath herself (stanzas 1, 2, and 4 ), and the speech of the elderly lady who is having the face lift (stanza 3). Here is the first voice:

7 I have discussed this aspect of Plath's poetry in my "Angst and Animism in the Poetry of Sylvia Plath," Journal of Modern Literature, 1 (First issue 1970), 57-74. 
When I was nine, a lime-green anesthetist

Fed me banana gas through a frog-mask. The nauseous vault

Boomed with bad dreams and the Jovian voices of surgeons.

Then mother swam up, holding a tin basin.

O I was sick.

These lines are reminiscent of many passages in The Bell Jar describing Sylvia Plath's own experience. The second voice is quite different:

I grow backward. I'm twenty,

Broody and in long skirts on my first husband's sofa, my fingers

Buried in the lambswool of the dead poodle;

I hadn't a cat yet.

It is difficult to believe that the "I" of these lines, the lady of sofas and poodles, would be capable of articulating the thoughts presented in the first two stanzas. In her later hospital poems, Sylvia Plath solved this problem by dropping all masks, by placing her own "I" squarely at the center of the poem as an object to be contemplated by the poem's inventor. "Fever $103^{\circ}$," for example, is a highly charged account of the poet's reaction to the delirium of high fever, a condition at once terrifying and thrilling, for it allows her to transcend her ordinary self and enter a pure deathless realm, a paradise where pain can no longer hurt:

I think I am going up,

I think I may rise-

The beads of hot metal fly, and I, love, I

Am a pure acetylene

Virgin

Attended by roses. ...

(My selves dissolving, old whore petticoats)-

To Paradise.

In discussing Crossing the Water, critics have been particularly enthusiastic about Sylvia Plath's moralized landscapes (the first group in my classification), arguing that here the poet shows that she is capable of writing excellent descriptive poetry, at once less mannered than that of The Colossus and less strident than the hallucinatory lyrics of Ariel. But despite Ted Hughes' suggestion that Sylvia Plath might have been another Elizabeth Bishop, had she chosen to stick to the descriptive mode, ${ }^{8}$ I cannot help thinking that much of the descriptive detail in the landscape poems is gratuitous. In "Wuthering Heights," for example, the poet, crossing the moors toward her house, is obsessed by the frightening emptiness of the landscape. As in "Parliament Hill Fields," the landscape

8 “Sylvia Plath's Crossing the Water," Critical Quarterly, p. 166. 
becomes the embodiment of her most deep-seated fears. The horizons "dissolve and dissolve," and the wind, which bends "Everything in one direction," is "trying/ To funnel [her] heat away." To identify with this world of grass, pale sky, and wind is to die, and the speaker is both tempted to give in and yet fearful lest she do: "If I pay the roots of the heather/ Too close attention, they will invite me/ To whiten my bones among them." The poet merges with the world of nature and knows what it is to be subhuman: "The grass is beating its head distractedly./ It is too delicate/ For a life in such company."

In these metaphors of animistic identification, the poet succeeds in drawing us into her circle of experience. But the intensity of the poem is diminished, at least for me, by certain passages in which the poet seems bent on being clever at all costs. Thus the sheep are described as "All wig curls and yellow teeth/ And hard, marbly baas"-a description which may be accurate enough, but one wonders how the speaker, in her disembodied state, could notice that the sheep's teeth are yellow. Or again, consider the last three lines of the poem:

Now, in valleys narrow

And black as purses, the house lights

Gleam like small change.

The comparison of narrow black valleys to change purses and of house lights seen in the distance to the small change one is happy to find at the bottom of the black purse may be ingenious, but the conceit does not provide effective closure. Unlike the reference to the "marriage dress, of that pallor" in the final line of "Little Fugue," which, as I argued earlier, has been anticipated by every image that precedes it, the black purse image, suddenly introduced at the end of "Wuthering Heights," breaks the spell of the preceding stanzas, calling attention to the poet's ability to make daring metaphors rather than to the intensity of her vision.

The same tendency to sacrifice intensity to ingeniousness spoils many of the other landscape poems. The title poem, for example, describes the sudden descent of night on the waters of a Canadian lake, a blackness so all-embracing that the poet, from the vantage point of her little rowboat, knows suddenly what death must be. One thinks of Hopkins' "Spelt from Sybil's Leaves" or Stevens" "Domination of Black" as possible models. The opening of the poem is intentionally low-key:

Black lake, black boat, two black cut-paper people.

Where do the black trees go that drink here?

Rapidly, Sylvia Plath conveys the sense that the speaker is being absorbed into the blackness of the lake, that her urge is not so much to cross the water as to drown in it. To introduce the image of the snag "lifting a valedictory, pale hand" in line 9 is therefore to overstate the case, to spell it out too neatly. Similarly, the final line reasserts rather flatly what we already know: that "This is the silence of astounded souls." 
It is entirely possible, of course, that had Sylvia Plath lived to supervise the publication in book form of such poems as "Crossing the Water," she would have revised the lines in question. Nevertheless, it seems excessive to say, as does Peter Porter in the New Statesman, that Crossing the Water is "full of perfectly realised works."9 The book's weaknesses-gratuitous description, overingenious metaphor, mannered sound patterning often unrelated to meaning, and occasional tonal and structural irresolution, as in the case of "Parliament Hill Fields"-are, I would argue, the very faults critics have noted in The Colossus. Some of the later poems in The Colossus, for that matter-"Mushrooms," "Blue Moles," "The Stones"-are more fully achieved works than any single poem in Crossing, with the possible exception of "I Am Vertical," that famous Roethkean poem describing the longing to become one with the flowers and trees. One cannot help wondering then, if Sylvia Plath would have cared to publish many of the poems in Crossing in book form at all, or whether Ted Hughes' posthumous edition of these "transitional poems" is not a disservice to her best work.

\section{III}

Winter Trees raises rather different issues. Setting aside the radio play "Three Women," which had already been published in the appendix of Charles Newman's The Art of Sylvia Plath, and the three poems printed in the U.S. edition of Ariel, this slim volume contains only fifteen poems (twenty-three pages in all). True, the poems stem from Sylvia Plath's "great period"-the last nine months of her life-and could easily be included in an expanded edition of Ariel since they burn with the same central passion to destroy the old ego and create a new self, to undergo death and rebirth, to enter the lives of animals, plants, or inanimate objects so as to transcend one's humanity. The nagging question that troubles the reader of these supplementary Ariel poems, however, is whether Sylvia Plath's range is not perhaps too narrow, whether a major poet, as Plath has been called by Alvarez and others, should not be capable of greater depth and variety.

Thus, many of the poems in Winter Trees which are very striking when read singly, begin to take on an air of déjà vu when one is familiar with Ariel. The imagery of hooks and wires, for example, referring to the mechanization of human relationships, can become monotonous:

Bright fish hooks, the smiles of women

Gulp at my bulk. . . .

(“Gigolo")

And we, too, had a relationship-

Tight wires between us,

Pegs too deep to uproot, and a mind like a ring

Sliding shut on some quick thing,

The constriction killing me also.

("The Rabbit Catcher")

9 New Statesman, 4 June 1971, p. 774. 
The air is a mill of hooks. ...

And my baby a nail

Driven, driven in.

("Brasilia")

Images of engulfment and constriction similarly become repetitive. The poet must always hide from a nameless threat:

Pocket watch, I tick well.

The streets are lizardy crevices

Sheer-sided, with holes where to hide.

It is best to meet in a cul-de-sac. . . .

("Gigolo")

In "Purdah," the speaker must pose as a meek concubine, submissive to her lord:



But all the time that she hides behind veils and "silk/ Screens, these rustling appurtenances," she is plotting the triumph of female over male, the death of the "bridegroom" who has oppressed her:

And at his next step

I shall unloose. ...

From the small jewelled

Doll he guards like a heart-

The lioness,

The shriek in the bath,

The cloak of holes.

This climactic ending with its allusion to the murder of Agamemnon, immediately recalls the brilliant conclusion of "Lady Lazarus":

Out of the ash

I rise with my red hair

And I eat men like air.

(Ariel, p. 9)

One wonders how frequently a poet can use this type of dramatic Gothic twist 
without dissipating its force. I have the same reservations about those poems that deal with nursing one's baby. "By Candlelight" (Winter Trees, pp. 28-29), for example, is surely an impressive rendition of the mixture of love and fear the poet experiences while nursing her infant in the small hours, but Sylvia Plath has treated this theme so frequently, using candlelight imagery that is all but interchangeable from poem to poem, that one begins to question the need for yet another version of the same thing:

These little globes of light are sweet as pears.

Kindly with invalids and mawkish women,

They mollify the bald moon. . .

The eyes of the child I nurse are scarcely open.

In twenty years I shall be retrograde

As these drafty ephemerids.

(“Candles," Crossing, pp. 24-25)

The candle

Gulps and recovers its small altitude,

Its yellows hearten.

O love, how did you get here?

O embryo. . . .

The pain

You wake to is not yours.

("Nick and the Candlestick," Ariel, pp. 33-34)

At first the candle will not bloom at all-

It snuffs its bud

To almost nothing, to a dull blue dud.

I hold my breath until you creak to life,

Balled hedgehog,

Small and cross. The yellow knife

Grows tall.

(“By Candlelight," Winter Trees)

Confronted by these candlelight poems, one begins to speculate that perhaps, in the case of Sylvia Plath's poetry, less is more. The lyric intensity of her vision somehow seems more impressive when one first meets it in the slim and rigorously selective Ariel than when it is placed in the perspective afforded by the publication of her uncollected poems. This is not to say that Sylvia Plath is not an important poet. The influence of her work on the diction, syntax, and imagery of younger writers-especially women-could hardly be greater today, and it shows no signs of abating. It was Sylvia Plath, after all, who took the poetic premises of Roethke, of Lawrence, or of Thomas to their logical conclusion, who 
showed contemporary poets that there was a viable alternative to the Projectivist mode on the one hand and the realist-confessional mode of Lowell and his followers on the other.

Nevertheless, a reading of Crossing the Water and Winter Trees suggests that Sylvia Plath's imaginative world is, despite its power and coherence, essentially a limited one. Alvarez has gone so far as to compare her to Keats, ${ }^{10}$ but surely Sylvia Plath was the Christopher Smart rather than the Keats of the early sixties, a poet who will be remembered less for a major oeuvre than for a handful of astonishing and brilliant poems, a fascinating autobiographical novel,11 and for the example of her life with its terrible tension between success and suffering-a tension peculiarly representative of her time and her place.

10 See The Savage God: A Study of Suicide (New York: Random House, 1972), p. 21. Alvarez writes of Plath's last work, "These months were an amazingly creative period, comparable, I think, to the 'marvelous year' in which Keats produced nearly all the poetry on which his reputation finally rests."

11 I discuss the novel at length in "'A Ritual for Being Born Twice': Sylvia Plath's The Bell Jar," Contemporary Literature, 13 (Fall 1972). 